\title{
Identification of deer and goat species from skin samples-a DNA barcoding approach
}

\author{
(iD) \\ (iD) \\ (iD \\ S. Maya1, Sanil George ${ }^{2}$, A.R. Sreeranjini ${ }^{3}$, C. Leena ${ }^{4}$, N. S. Sunilkumar ${ }^{4}$ and K.B. Sumena ${ }^{4}$ \\ Department of Veterinary Anatomy and Histology, College of Veterinary and Animal Sciences, Mannuthy. \\ Kerala Veterinary and Animal Sciences University, Pookode.
}

Citation: Maya, S., Sanil, G., Sreeranjini, A. R., Leena, C., Sunilkumar, N. S. and Sumena, K.B. 2021. Identification of deer and goat species from skin samples-a DNA barcoding approach. J. Vet. Anim. Sci.52(1): 85-87. DOI: https://doi.org/10.51966/jvas.2021.52.1.85-87

Received : 08.12.2020

Accepted: 23.12.2020

Published: 01.01.2021

\begin{abstract}
DNA barcoding is a technique for characterizing species of organisms using a short DNA sequence from a standard and agreed-upon position in the genome. In the present study, DNA barcoding was used as a technology to differentiate deer and goat species from the skin samples. The samples were collected from different regions of the skin, viz. ear pinna, dorsal abdomen, muzzle and interdigital space of foerelimb of deer brought for post mortem at College of Veterinary and Animal Sciences, from Thrissur zoo and forest department and of goat freshly slaughtered in Meat Technology Unit, Mannuthy. Samples were chopped and preserved in ethanol and processed. The mitochondrial sequence of Cytochrome C Oxidase subunit (COI) was deliberated as a barcode marker suited best for species identification of the animals and based on this the samples were identified as Cervus unicolor, Rusa timorensis and Capra hircus. The results recommended that unidentified specimens from wild animals can be recognized competently using DNA sequencebased analysis.
\end{abstract}

Keywords: Deer, DNA barcoding, goat, skin

DNA barcoding is a technique for characterizing species of organisms using a short DNA sequence from a standard and agreed-upon position in genome. It is one among the most authoritative tools for discriminating species from minute pieces of biological specimens, as well as processed produces. It is a suitable tool for wild animal forensics (Ferri et al. 2009). Mitochondrial DNA (mtDNA) is seen in all eukaryote cells and has a relatively fast mutation rate. Eventhough significant variation occurs in mtDNA sequences between species, only small comparative variance is seen within species. All mtDNA genes are maternally inherited and hence more constant. A 658bp region (Folmer region) of mitochondrial cytochrome $c$ oxidase subunit I (COI) gene is being proposed as a potential 'barcode'. Mitochondrially encoded cytochrome c oxidase I (MT-CO1)- is a protein and that in humans has been encoded by MT-CO1 gene. In other eukaryotes, gene is called cox 1 or $\mathrm{COI}$ and forms the main subunit of cytochrome $\mathrm{c}$ oxidase complex. The advantage of using $\mathrm{COI}$ is that it is short enough to be sequenced quickly and cheaply, yet long enough to identify

1. Professor and Head and corresponding author, email - maya@kvasu.ac.in; Mob: 9446625160

2. Senior scientist, Rajiv Gandhi Centre of Biotechnology, Thiruvananthapuram, Kerala-695014

3. Associate Professor

4. Assistant Professors

Copyright: (C) 2021 Maya et al. This is an open access article distributed under the terms of the Creative Commons Attribution 4.0 International License (http://creativecommons.org/licenses/by/4.0/), which permits unrestricted use, distribution, and reproduction in any medium, provided the original author and source are credited. 
variations among species. In the present study, DNA barcoding was used as a technology to differentiate deer and goat species from the skin samples.

\section{MATERIALS AND METHODS}

Verythin samples of skinwerecollected from ear pinna, dorsal abdomen, muzzle and interdigital space of forelimb of deer brought for post mortem at College of Veterinary and Animal Sciences, from Thrissur zoo and forest department and of goat freshly slaughtered in Meat Technology Unit, Mannuthy. Samples were chopped, preserved in absolute alcohol (ethanol). Samples were sent; processed for DNA barcoding to laboratory at Rajiv Gandhi Centre of Biotechnology, TVM, where reference barcode sequences were generated to identify species of wild animals in Kerala. DNA analysis was done to establish identity. Samples were cut into small pieces, powdered finely using liquid nitrogen. The material weighing upto 250 $\mathrm{mg}$ was added to $2 \mathrm{ml}$ Eppendorf tubes having $500 \mu$ of lysis buffer (100 mM Tris- $\mathrm{HCl}, \mathrm{pH}$ 8; 5 $\mathrm{mM}$ EDTA, $50 \mathrm{mM} \mathrm{NaCl}, 20 \%$ (w/v) SDS and $25 \mathrm{ml}$ of Proteinase $\mathrm{K}$ [50 mg/ml]), vortexed for 30 s and incubated overnight at $37^{\circ} \mathrm{C}$. DNA extraction (Sambrook et al. 1989) was done with the digested materials following phenol: chloroform method. GFXTM PCR DNA and Gel Band Purification Kit (GE Healthcare) was used to purify the extracted DNA. CO1 gene was subjected to PCR amplification in a volume of $25 \mu \mathrm{l}$ containing 1 X PCR Gold Buffer, $2.5 \mathrm{mM}$ $\mathrm{MgCl}_{2}, 0.2 \mathrm{mM}$ of each of dNTPs, $20 \mathrm{pM}$ each of forward and reverse primers $\mathrm{LCO}$ and $\mathrm{HCO}$ (Folmer et al. 1994), three units of AmpliTaq Gold polymerase (Applied Biosystems) and 20-40 ng of purified DNA.

Amplification was carried out for an initial $10 \mathrm{~min}$ at $94^{\circ} \mathrm{C}$; followed by 40 cycles at $94^{\circ} \mathrm{C}, 45^{\circ} \mathrm{C}$ and $72^{\circ} \mathrm{C}$, each for $1 \mathrm{~min}$; and a final elongation step for $5 \mathrm{~min}$ at $72^{\circ} \mathrm{C}$ in a GeneAmpR PCR System 9700 (Applied Biosystems). PCR products were confirmed in $2 \%$ agarose gel stained with ethidium bromide. Sequencing reactions were carried out using Big Dye Terminator v3.1 Cycle Sequencing Kit (Applied Biosystems) using forward and reverse primers independently following manufacturer's instructions (www.ibt.It/sc/files/BDTv3.1_
Protocol_04337035.pdf). Sequencing products were purified and sequenced on an Applied Biosystems 3730 DNA Analyser.

\section{Results and Discussion}

The mitochondrial sequence of Cytochrome C Oxidase subunit (COI) is an ideal barcode marker suitable for species identification of the animals and based on this the samples were identified as Cervus unicolor, Rusa timorensis and Capra hircus.

Nucleotide sequence similarity search in NCBI (Accession No. KF317912.1) yielded most similarity with Rusa unicolor (identity 99\%); Cervus unicolor (identity 98\%) and Rusa timorensis (identity 98\%)for $\mathrm{COI}$ with reference sequences of Deer species for deer specimens.

Nucleotide sequence similarity search in NCBI (Accession Nos. KF317913.1; AB736109.1; KC679017.1) yielded most similarity with Capra hircus (identity 99\%) for $\mathrm{COI}$ with reference sequences of goat species for goat specimens.

The sequences of present study, were aligned along with sequences of closely related species obtained from GenBank and MEGA v3.1 software was used (Kumar et al. $2004)$ to create neighbor joining (NJ) tree of $\mathrm{K} 2 \mathrm{P}$ distances. The samples from the present study were identified as Cervus unicolor, Rusa timorensis and Capra hircus. Samples confirmed as belonging to sambar deer and goat. Study supports that the mitochondrial sequence of Cytochrome $\mathrm{C}$ Oxidase subunit (COI) is an ideal barcode marker suitable for species identification of the animals. From this study it was evident that mitochondrial CO1 can differentiate sambar deer and goat.

The expanding use of $\mathrm{COI}$ as genetic marker for animal species identification (Linacre and Tobe, 2011) can be highlighted by DNA barcoding. Present study differentiated the skin samples of sambar deer and goat. It is found that the accuracy of DNA barcoding will be dependent on data quality of database. Erroneous identification of species may result in misinterpretation based on DNA sequences 
present in database. Hence, updating the reference datasets (Parson et al. 2004) is of utmostimportance. The present study elucidates that barcode sequences may be applied for identification of species from even small pieces of material brought as evidence and therefore, stress the need of localized reference datasets for application in wildlife forensics. Thus it is concluded that DNA sequence-based analysis will be of use the effective identification of even unrecognizable wildlife specimens.

\section{Conclusion}

DNA barcoding was used to differentiate deer and goat species from the skin samples in the present study, which suggested that grotesque wildlife specimens can be recognized effectively by DNA sequencebased analysis. The mitochondrial sequence of Cytochrome C Oxidase subunit (COI) is an ideal barcode marker suitable for species identification of the animals and based on this the samples were identified as Cervus unicolor, Rusa timorensis and Capra hircus. Nucleotide sequence similarity search in NCBI (Accession No. KF317912.1) yielded most similarity with Rusa unicolor (identity 99\%); Cervus unicolor (identity 98\%) \&Rusa timorensis (identity $98 \%)$ for $\mathrm{COI}$ with reference sequences of Deer species for deer specimens. Nucleotide sequence similarity search in NCBI (Accession Nos. KF317913.1; AB736109.1; KC679017.1) yielded most similarity with Capra hircus (identity 99\%) for COI with reference sequences of goat species for goat specimens.

\section{Acknowledgement}

The financial assistance extended by the Animal Husbandry Department and the administrative help rendered by the Kerala Veterinary and Animal Sciences University in conducting the research are gratefully acknowledged.

\section{References}

Ferri G., Alu M., Corradini B., Licata M., Beduschi G. 2009.Species identification through DNA 'barcodes'. Genet-Test. Mol Biomark. 13: 421-426.

Folmer O., Black M., Hoeh W., Lutz R., Vrijenhoek R. 1994. DNA primers for amplification of mitochondrial cytochrome c oxidase subunit I from diverse metazoan invertebrates.Mol Mar Biol Biotechnol. 3: 294-299.

Kumar S., Tamura K., Nei M. 2004. MEGA3: integrated software for molecular evolutionary genetics analysis and sequence alignment. Brief Bioinform. 5: 150-163.

Linacre A., Tobe S.S. 2011.An overview to the investigative approach to species testing in wildlife forensic science. Investig. Genet. 2: 2. doi:10.1186/2041-22232-2.

Parson W., Brandsta" tter A., Alonso A., Brandt N., Brinkmann B., Carracedo A., Corach D., Froment O., Furac I., Grzybowski T., Hedberg K., Keyser-Tracqui C., Kupiec T., Lutz-Bonengel S., Mevag B., Ploski R., Schmitter H., Schneider P., Syndercombe-Court D., Sørensen E., Thew H., Tully G., Scheithauer R. 2004. The EDNAP mitochondrial DNA population database (EMPOP) collaborative exercises: organisation, results and perspectives. Forensic. Sci. Int. 139: 215-226.

Sambrook J., Fritsch E.F., Maniatis T. 1989. Molecular cloning: a laboratory manual. 2nd ed. New York: Cold Spring Harbor Press. 